\title{
“Overcome your anger if you are a man": Silencing women's agency to voice violence against women
}

\author{
Selin Akyüz ${ }^{\mathrm{a}, *}$, Feyda Sayan-Cengiz ${ }^{\mathrm{b}}$ \\ a Bilkent University, Ihsan Dogramaci International Advanced Studies Centre, Ankara, Turkey \\ b Istanbul Bilgi University Faculty of Communication, Department of Media, İstanbul, Turkey
}

\section{A R T I C L E I N F O}

Available online 4 May 2016

\begin{abstract}
S Y N O P S I S
This study traces the relation between male violence and masculinist norms that attribute political agency exclusively to men. Through critical analysis of a recent campaign initiated as an effort to fight violence against women in Turkey by addressing men as the only agents endowed with agency to solve the problem, we explore the ways in which this discourse risks marginalizing women who seek empowerment through women's solidarity. We uncover three patterns: (1) the assumption of a "cultural particularity" in Turkey nested in the traditional family structure which should allegedly be left unquestioned; (2) glorification of values attributed to the masculine; (3) taking violence as an individual problem of "anger management." We argue that this campaign is inimical to the aim it declares because by marginalizing feminist efforts to question the social and structural patterns of male violence, it deprives women of political agency essential in the struggle against this problem.
\end{abstract}

(C) 2016 Elsevier Ltd. All rights reserved.

\section{Introduction}

A short film opens with a man leaving his house in the morning. He is shaven and wears a clean, smart suit. He starts walking in his neighborhood, smiling, and greeting people all around. Apparently, everyone knows him, but there is an air of uneasiness: a gardener and elderly neighbors refuse to greet him, giving him accusing glances. Even little boys give him the cold shoulder. Then an authoritative, almost angry male narrates: "Did you think that we would take you for a man?" At that moment, the camera pans to the man's house from the outside. From between the curtains, there is a mere shadow of him hitting a woman, presumably his wife. The short film concludes with the voiceover, almost to the point of shouting: "Those who hit women are not men! Be a man first!"

The short film is part of a campaign in Turkey to battle male violence against women. The slogan, "Be a man first," is the follow-up to a 2013-slogan of "Overcome your anger if you are a man." The campaign is organized by KADEM (Women and

\footnotetext{
* Corresponding author.
}

Democracy Association), a relatively new woman's organization. As a conservative association, KADEM's vision is "conserving the essential values of women in Turkey." ${ }^{1}$ The short film contains striking moments that convey messages similar to the slogans of the campaign. In step with the slogans addressing only men, there are no women among the "people of the neighborhood"; even the kids are boys playing football: The message conveyed in the film is all about men, men beating their wives, and other men giving them the cold shoulder, through symbolic gestures of disapproval. Apparently, violence is a secret that is disapproved of and that "everyone knows but no one (in the neighborhood) talks about." The audience only sees violence through the curtains of the home: while watching the shadows, the spectator is made to feel like an intruder into the sanctity of the "private space." Even more interesting is the fact that the battered wife does not even have a body: she is a mere shadow reflected on the wall of her home. She has no voice.

Violence against women is a major human rights issue. According to a study conducted by the World Health Organization (WHO), 35 \% of women around the world 
experience physical and/or sexual violence at some point in their lives. ${ }^{2}$ Among the most pervasive types of violence against women is intimate partner violence, which damages a woman's physical, psychological, sexual, and social integrity. In Turkey, the numbers are by no means better than the world average. According to the latest national research carried out by Turkey's Directorate General on the Status of Women (DGSW), “39.3\% of women reported having experienced physical partner violence, $14.3 \%$ of them reported sexual violence, $43.9 \%$ emotional violence, $23.4 \%$ economic violence at any time in their life" (Güvenç et al., 2014: 334). According to the data recorded by Bianet, an online communication network following cases of male violence in national, local, and internet media, in 2014 , at least 281 women were killed by men while 190 women were raped and 140 women were sexually abused. ${ }^{3}$ Despite positive developments in the legal framework, such as the adoption of a new domestic violence law, namely Law no $6248,{ }^{4}$ violence against women has not decelerated its increasing trend. Although amendments to the country's Penal Code hinted at political gains by recognizing government's responsibility for providing shelter to victims of domestic violence, not much progress has been made. In power since 2002, JDP (Justice and Development Party) government evinced the party's anti-feminist stance by advocating "a neoliberal conservative version of patriarchy" marking "the familial sphere as the natural locus of women" (Coşar and Yeğenoğlu, 2011: 567). Within the neoliberal restructuring of the country, the JDP's family focused policies as well as discussions concerning women's bodies and reproductive functions have reaffirmed that Turkish women's bodies have become a battleground for political actors. Instances of discussion include government attempts to ban abortion, emphasis on motherhood as "the central career for women," and President Recep Tayyip Erdoğan's (former JDP leader and Prime Minister) "advice" for bearing at least three kids (Onar \& Müftüler-Baç, 2011; Ünal \& Cindoğlu, 2013). Such a formulation packs the patriarchal view of the government aligning with an anti-feminist agenda by not recognizing women's autonomy. This is the backdrop that should be considered when analyzing KADEM's "Overcome your anger if you are a man!" campaign.

KADEM was founded in 2013, with the mission of "formulating common public awareness in society in terms of women's rights and equal opportunities with the family and in social roles." ${ }^{5}$ In this way, the organization has aligned itself with the government's conservative position by situating the woman within the boundaries of the family. In addition, their vision of "preserving the Turkish women's essence while elevating her to a compatible position with women all around the world in national and international platforms"6 emphasizes cultural essence and hints at the idea of conserving traditional gender roles.

In declarations regarding their campaign, KADEM officials emphasize that they aim to address men and give them the central role in seeking solutions to the problem. Indeed, this objective at first seems compatible with global trends in the struggle against male violence: there are several campaigns and programs conducted by governments and civil society organizations to engage men in this struggle "as participants in education programs, as targets of social marketing campaigns, as policy makers and gatekeepers, and as activists and advocates" (Flood, 2011: 358). Scholarship exploring the relationship between masculinity and violence discusses how to mobilize men against male violence without losing critical perspectives on masculinist norms and patriarchal relations of domination (Seymour, 2011; Greig, 2001). Analyzing the KADEM campaign and its slogan "Overcome your anger if you are a man" is particularly of significance for this discussion as it lays bare the risks of abandoning the critical perspective on masculinities in the name of addressing and engaging men. In this paper, we delineate the ways in which the campaign becomes counterproductive by normalizing masculinist norms and patriarchal relations of domination, even to the point of reserving the agency to deal with the issue exclusively to men and excluding women from the struggle. While the campaign calls men to simply "be men" in an effort to fight violence against women, it bears the danger of ossifying and reinforcing patterns of male domination as it avoids a critical questioning of the connotations attributed to "being a man."

This article discusses the campaign's three interconnected lines of argumentation which form the discursive ground on which the slogan "Overcome your anger if you are a men" rests. The first pillar is the emphasis on "cultural particularity" and the centrality of the traditional family structure in Turkey. The second pillar is the argument that men and only men are the agents who will solve the issue of violence and that a relevant campaign should avoid conflicting with social codes of masculinity and stay on "men's good side" in a bid to convince them to stop being violent. The third pillar relies on the argument that male violence is a "personal," "individual" issue of anger management, therefore solutions to this problem are at the individual level. All in all, this discursive ground diverts attention from the problem of patriarchy and promotes a view of male violence stripped from patriarchal relations of power and domination.

\section{Drawing theoretical boundaries: Revisiting normalized gender hierarchies}

Before analyzing the campaign in detail, this section draws theoretical boundaries that the analysis is based on. It is significant to revisit the male-centered political domain with its embedded discourses and meanings as it offers the ways in which normative masculine domination is reproduced. This study employs the conceptual framework of critical masculinity studies to understand the reproduction of normative masculine domination and its role in breeding male violence. We argue that in order to understand the reproduction of masculine domination, it is essential to explore, first, the relational construction of a gender order, in other words "how masculinities and femininities are produced together in the process that constitutes a gender order" (Connell, 1995: 72), and second, to analyze this relational construct within the specific historical, social, and political context it is produced.

Scholars of gender studies have problematized male violence as the most visible form of masculine domination. ${ }^{7}$ Considering that "interpersonal violence is about power and the negotiation of power relations and it is also organised along gender boundaries" (McCarry, 2007: 412), it is vital to understand unequal gender hierarchy and the gender order it generates as the context that breeds male violence. As McCarry 
puts it, "the literature on men and masculinity would be an obvious starting point" (2007: 412).

Connell (2002) underlines the significance of analyzing the historical, institutional, and discursive contexts in which both the gendered power hierarchy and an unequal gender order are reproduced. It is this order that students of gender aim to critically analyze. Embracing this perspective, our critical analysis of the KADEM campaign is embedded in an analysis of historically, socially, and politically constructed gendered norms in contemporary Turkey. Within this context, what meanings does the campaign generate? Which discourses does it tap into? What norms of masculinity and femininity are encouraged? Which possibilities and which struggles are pushed to the margins through campaign's discourse?

With the revival of the feminist movement, "varied theories developed to explain the causes of male domination, to correct erroneous assumptions about both women and men, and to imagine new kinds of men and of women in new circumstances" (Kegan Gardiner, 2005: 36). Men and masculinity studies have been contributing to this theoretical terrain since the late 1970s. Initially, researchers and scholars of men and masculinities aimed to broaden the historically myopic perspective of gender scholars who conflated gender studies with women's studies. The prominent terms of the first wave of masculinity studies, in the 1970s, simply revolved around a discussion on restrictions, disadvantages, and general penalties attached to being a man (Connell \& Messerschmidt, 2005; Kimmel, Hearn, \& Connell, 2005). This early wave of masculinity studies questioned how the system has victimized men, or in other words, how men have been oppressed by the gender roles attributed to them. This was followed by a shift of focus to the notion of "masculinities" in the late 1980s. Scholars have tended to agree that there is a need to think of masculinity not as a singular sex role but as multiple, contextual constructions. Connell introduced the concept of hegemonic masculinity which in turn raised the discussion about different forms of masculinity. For Connell, hegemonic masculinity is constructed in relation to various subordinated masculinities as well as in relation to women (Connell, 1987: 183). Accordingly, hegemonic masculinity not only grasps men's patriarchal dominance over women but also hegemony of some masculinities over others, highlighting hierarchical classifications of masculinities (Connell, 1987, 1990). While pointing out the processes that create hegemony, subordination, complicity, and marginalization among masculinities (Connell, 2005), Connell also emphasizes how models of emphasized femininity are crucial, as "patterns of masculinity are socially defined in contradistinction from some model (whether real or imaginary) form of femininity" (Connell, 2005: 848).

The critical studies of men and masculinities, in general, the concept of hegemonic masculinity, in particular, provided researchers with new possibilities to re-visit gender analyses of states, systems, cultures, ideologies, and violence. It is through this conceptual framework that this study explores the processes in which the relational constructions of masculinities and femininities shapes political discourses that exclude women from the public political realm and devoid them of political agency even in the struggle against male violence which directly concerns their bodies and livelihoods.

McCormack's (2007:1) pertinent question of "why have men traditionally been associated with the public political domain and what implications (does) this have for gender relations as a whole?" recognizes that it is not only conceptualizations of femininity but those of masculinity which are actively created and fostered through processes of inculcating common values and behaviors, constructing power relationships, or negotiating the boundaries of inclusion and exclusion. Thereby, it is critical to revisit how perceived dichotomies are gendered and the implications of these dichotomies for gender relations. Especially, in the framework of negotiating/drawing the boundaries of exclusion and inclusion that has resulted in the dichotomized replacements of men and women into different spheres, it is important to analyze gendered consensual norms. As the literature on gendered distinction between public and private realms argues, political discourse has been shaped by constituting femininity as "the other" (Pitkin, 1984; Pateman, 1988; Kann, 1998). This discourse is "male centered, as if men were doing what came naturally when they presumed to monopolize power and ignore women's potential or presence as public persons" (Kann, 1998: 18). Since ancient Greece, theorists have "associated manhood with wisdom, virtue and citizenship but tied womanhood to dangerous, disorderly and irrational forces" and thereby shaped the main contours of the gendered boundaries (Hartsock, 1983 cited in Kann, 1998: 16). In Bourdieuian terms, this "honorific award of culture" has naturalized and normalized gender hierarchies (Bourdieu, 2001). Along the same lines, for Brittan, the naturalization of male power has relatively remained constant and, attributing some aspects of men's behaviors, such as aggression and insensitivity, were "based on the idea that there is something about men which transcends their local situation." (1989:4). Similarly, Hawkesworth argues that gender symbolism, generating a logic in which rationality, competence, and leadership are coded as masculine, is embedded in "(...) structures of belief that constitute the identities and aspirations of gendered political agents" (2005: 150). That is how the masculine has become normal and also normative as political institutions, discourses, and agents have traditionally been guided by a discourse of objective reasoning and rationality. Women with their traditional supporting roles remain outside this "traditional remit" of the political sphere (Hooper, 2001: 92). Consequently, gendered hierarchies are reproduced and patterns of male authority are legitimized through the domination of "a grammar of manhood"(Kann, 1998:3). This dominant "grammar of manhood" that is employed by the political elites to stabilize political authority is encapsulated by a "culture of manhood" (Connell, 2005). This "culture of manhood" consistently naturalizes the superiority of masculine characteristics. Following this conceptualization, this study specifically defines political masculinities within the multilayered network of politics. In line with Starck and Sauer's definition of political masculinities, our definition embodies "any kind of masculinity traits that is constructed around, ascribed to and/or claimed by political players" (2014: 6, emphasis ours).

To put it more bluntly, in this study, we take the political domain as a network which is not limited to political institutions or the political elite, but which encapsulates the discursive realm in which certain agents are almost "naturally" ascribed political agency, while others are excluded. As the masculinity literature suggests, these processes of exclusion and inclusion are highly gendered and have their basis in the 
normalized formulations of "culture of manhood." Through socially created and symbolically idealized masculinities, the reproduction of hegemonic norms found the fertile ground to flourish with the help of the political agents.

\section{Gendered metaphors: Carriers of the culture of manhood}

In order to trace the root of these conventional social discourses that reproduce hegemonic masculine norms, it is useful to look into the gendered metaphors that are widely used in Turkey's political realm. Parpart and Zalewski claim that " $(. .$.$) metaphors act as motors of discourse which work to$ frame and naturalize masculinist assumptions." (2008: 10). Similarly, Bora and Tol (2009) draw attention to the defining metaphors which figure as "motors of discourse" in naturalizing the construction of Turkish politics as a masculine realm. The most common example is the metaphor of er meydan (arena of man) to describe the field of Turkish politics as an "arena" where men display their power and "manliness." It is very common among Turkish political leaders to "invite" their opponents to er meydam for a test of manliness and strength. The metaphor is especially interesting as it refers to the arena (er meydanı) where the traditional, ancestral, and exclusively masculine sport of oil wrestling takes place. This sport is especially renowned for the annual Kırkpınar tournaments that attract tourists to Edirne, a city in western Turkey. In these tournaments, the most successful oil-wrestlers engage in competitions, publicly displaying their muscular andoiled bodies. It is practically a show where the male body and its power are glorified, celebrated, and rewarded. More importantly, er meydan, where oil wrestling takes place, is a strictly virile field, "defined" by the exclusion of the female.

It is indeed interesting that a metaphor which loads politics with such exclusively and extremely masculine connotations has been normalized in the political rhetoric in Turkey. Whereas political leaders "invite" their opponents to er meydanı, this invitation never remains ignored by other politicians. The metaphorical confrontations continue through invitations to "tests of courage" in which men, the main actors of politics, should display manly bravery instead of being fragile or sensitive "like women".

Bora and Tol (2009) also argue that the masculinist necessity manifests itself in the male body as the main agent within the field of politics, meaning that the metaphors reinforcing dominant norms of hegemonic masculinity are undergirded by the assumption that every political actor is male. Whereas Bora and Tol highlight the politicians involved in institutional politics, it is possible to argue that the main interlocutors and addressees of this masculinist political discourse are also assumed to be men. In line with the argument that deep-rooted symbolic associations construct man as the natural holders of power (Yanagisako \& Delaney, 1994: 3), the symbolic idealizations in Turkish political discourse reserve political agency to men as well. Whereas men are situated as the main political agents, women are excluded from holding political agency. In addition to the use of gendered metaphor of er meydani, there are other gendered expressions that define the parameters for a decent person such as adam gibi or erkek gibi (both meaning "like a man"). These are commonly used examples of the language of manhood. They define a set of norms, i.e. toughness, integrity, appositeness, and expect "men and/or individual" to behave accordingly. In this framework, it can be argued that Turkish politics as a field has never been estranged from gendered images.

\section{“Shout out": Calling women to fight against male violence}

In this section, we explore the ways in which women's movements in Turkey have handled the gendered hierarchies and norms that assume men as the natural political agents while pushing women to an eternal position of silence and "otherness." We especially look into the ways the post- 1980 women's movement came up with to challenge these norms and suggest that the struggle against male violence has given this movement its primary momentum in terms of establishing women's activism as an autonomous actor in the stage of political life.

Turkey's early republican history is permeated with paradoxes regarding the "women question." Even though the modernization process in the early Republican period dramatically changed women's lives by integrating them in public and political life, the gender politics of this era have largely been scrutinized for repressing women's autonomous organization (Tekeli, 1986; Zihnioğlu, 2003) and bringing about a transformation that does not challenge the patriarchal limits in the realm of political life (Arat, 1989; Berktay, 2001; Kandiyoti, 1987). The trajectory of the women's movements in Turkey demonstrates different paths through which women have responded to these patriarchal limits. In attempts to periodize the women's movement in Republican Turkey, the most significant distinction is drawn between Kemalist women's activism and the feminist movement that emerged in the post1980 period (Arat, 1999; Coşar \& Yeğenoğlu, 2011; Sirman, 1989). The pre-1980 era women's movement is defined either by the Kemalist-oriented women's organizations, which remained within the limits of "state feminism" (Tekeli, 1986: 193) or leftist oriented women's organizations that framed their demands within the limits drawn by the socialist movement (Özçürümez \& Sayan-Cengiz, 2011; Tekeli, 1986). In other words, it has been argued that there were shortcomings in terms of developing autonomous feminist demands and defining women's issues as politically significant issues in their own right (Akal, 1996; Tekeli, 1990). The post-1980 feminist movement, on the other hand, not only detached itself from other (Kemalist or socialist) ideological frames but also critically examined the way those frames silenced women's autonomy and political agency (Tekeli, 1986, 1990).

Building on the argument that the post-1980 feminist movement struggled toward establishing women as autonomous actors in public and political life, we suggest that the feminist struggle against male violence enabled posing a challenge to masculinist political discourse mainly in two ways: First, by asserting that male violence in the domestic realm is a structural thus political problem, it complicates the dichotomy of "public vs. private/personal" and challenges the idea that "domestic" violence is a problem to be relegated to the "private/personal" realm. Second, by addressing women as political agents who will seek solutions to this deeply rooted problem through solidarity and struggle.

The women's movement in the post-1980 era in Turkey started with grassroots activism in the form of small 
consciousness raising groups which paved the way for a new feminist discourse and emboldened women's solidarity against structural patriarchy deeply rooted in various walks of political and social life. Perhaps the most crucial contribution of these groups was to help women find their "voice"8 through sharing their experiences of being subjugated. It was through the sharing of experiences that an awareness of how the established masculinist norms at the public and political level and at the level of intimate relations interpenetrate and reproduce each other.

The post-1980 feminist movement gained nationwide recognition and publicity through the Campaign against the Battering of Women, and the Women's March Against Violence in 1987 which was the first massive street demonstration of the post-coup era. Moreover, this march marked the first time "women took to the streets themselves, for their own problems, with an organization of their own" (Savran cited in Altınay \& Arat, 2008: 18). Sirman notes that the Campaign against the Battering of Women "served as a focus point around which different (feminist) groups have rallied and cooperated" (1989:7). The Women's March against Violence and the following meetings, festivals, and publications not only provided the movement with recognition and publicity in the national media but also started the process of "naming" violence against women as a public and political issue. In 1988 , following the Campaign against the Battering of Women, feminist women published a book titled "Shout and be Heard," which consisted of the experiences of battered women. The book further called women to voice their experiences of being subjected to male violence and to bring those experiences to public attention without being ashamed or intimidated. The main objective of the book was to make the point that what had been categorized as a "personal" issue is in fact a common experience of structural oppression in women's lives, which can be overcome only by the solidarity of women. This notion is captured in the following statement in the book: "Personal is political... We need to expose that the issues presented as personal problems are actually the common problems of an oppressed group." 9 In other words, women were called to voice male violence rather than cover it up under the "sanctity" of the family. It was also an empowering call because women were addressed as "the political agents" who would bring the issue to the public realm of discussion.

The current struggle against male violence has a history steeped in the history of Turkey not limited to the early 1980's activism. A detailed account of this history is beyond the scope of this paper. ${ }^{10}$ Yet, the discourse of women's solidarity against structural patriarchy interpenetrating the level of intimate relations as well as public and political levels had its seeds sown during the post-1980s feminist activism. It is this discourse that acted as a lever to carve out a space for autonomous women's activism.

The discourse of the post-1980 feminist movement in Turkey resonates with second wave feminism, especially with regard to bringing "the personal" within the realm of "the political," hence extending the boundaries of the latter. In other words, vital issues such as male violence and sexual harassment, which had been formerly relegated to the "personal" realm, were "named" and brought to public attention as structural problems stemming from the established gender ideology and deeply rooted patriarchy.
The novelty of second wave feminism lies in the exploration of male oppression in the "personal" realm, such as the family and everyday life experiences of women (Bryson, 1992). Indeed, it is possible to suggest that this is exactly what constituted the fundamental challenge presented by the post-1980 movement in Turkey, and further, that making the male violence in the domestic realm visible was the foremost component of this challenge.

To put it in a nutshell, the women's struggle against male violence figured as a defining struggle in the post-1980 feminist movement's challenge against dominant codes of masculinity that define men as "the natural players" of the political field, entitled to determine its borders. The post-1980 women's movement claimed to redefine the borders of the political by pointing out how the violence pervading intimate relations is embedded in the structural, gendered relations of domination that permeate social and political fields. This process goes hand in hand with exposing the connection between male violence against women and the established masculinist norms that assign men the tasks of being powerful, potent, and authoritative. Consequently, the movement defined women as political agents who would carry out a political struggle in solidarity with each other. Through defining women as political agents who would speak out about the violence in the household, the movement challenged the model of hegemonicmodels of silent, docile femininity that are constructed in relation to the norms of hegemonic masculinity.

\section{What is in a slogan: "Overcome your anger if you are a man"}

Taking this historical context into consideration, it becomes even more important and urgent to analyze the recent campaign against violence publicized with the slogans "Be a man first" and "Overcome your anger if you are a man." The discourse surrounding the campaign stands in sharp contrast to the post-1980 feminist discourse which exposes and challenges patriarchal relations of domination through establishing networks of women's solidarity and calling women to be vocal about the structural patterns breeding male violence. This campaign gives us a sharp and condensed snapshot of a conservative perspective on male violence and how, contrary to the feminist emphasis on women's agency and solidarity, it reserves agency exclusively to heterosexual men in the effort to prevent male violence, in turn reinforcing a certain model of hegemonic masculinity.

KADEM, the women's organization conducting the campaign was established in 2013 and enjoys the support of the incumbent conservative JDP government, as well as the explicit support of Turkey's president, Recep Tayyip Erdoğan. ${ }^{11}$ For instance, in a November 2014 speech at a KADEM summit, Erdoğan stated that "among other women's NGO's, KADEM is exceptionally successful in terms of its discourse and alternative ideas." This was the same speech in which Erdoğan argued that men and women cannot be equal, for equality is against "fitrat," the Islamic concept denoting natural disposition. ${ }^{12}$

The president of KADEM, Sare Aydın Yılmaz, seems to share President Erdoğan's ideas on gender equality. In an opinion piece, she wrote in the national daily newspaper Star she suggests that the concept of "justice" is more in tune with the needs of society in Turkey than the concept of "equality" (Aydin Yilmaz, 2014). At the same time, she blames Turkey's women's 
movement in a wholesale fashion, without acknowledging the distinctions among different strands of the movement, for being stuck on the 19th-century concept of "equality." Through this argument, she is referring to the age-old equality vs. difference debate, which had already been on the women's movement's agenda for decades in Turkey (Arat, 1997). Besides glossing over this information, she does not suggest engaging in a discussion about what substantive gender equality would entail. Instead, she argues that gender equality should not be a goal and suggests giving weight to the concept of "justice," which, according to her, is superior to equality because it acknowledges the fitrat of women and the need to protect them due to their fitrat.

\section{Discursive limits in arguments supporting the campaign}

The KADEM campaign publicized under the slogan "Overcome your anger if you are a man" rests within the broader discursive context which aims to displace the concept of gender equality in favor of the concept of "justice" based on the assumption of natural born inequalities between men and women. This section looks into the main lines of argumentation employed in support of the campaign by conducting a content analysis of documents published on KADEM's website; interviews with the president of KADEM in national daily newspapers, and all the columns published between November and January 2014 in national daily newspapers that lend support to the campaign and its slogans. The websites of national daily newspapers were scanned with the keywords "KADEM" and "erkeksen" (if you are a man). The period between November and December 2013 was selected as the slogan "Overcome your anger if you are a man" was launched in November 25, 2013, followed by a series of newspaper columns promoting the campaign. We focus on columns that support the campaign because the purpose of the study is to delineate and analyze the discursive ground within which the slogan rests, as well as to point out the limits and paradoxes inherent in this ground.

We distinguish three salient lines of argumentation in the data. The first line emphasizes an alleged "cultural particularity" in Turkey, especially with regard to gender relations, and the centrality of the family to this "cultural particularity." The second line of argumentation emphasizes that it is essential to speak to and reconcile with men, in other words to act in a consensual rather than a conflicting manner in the struggle to end male violence. While inviting men to live up to the values attributed to "the masculine," the norms of hegemonic masculinity are reinforced and glorified. In this line of argumentation, feminist concepts such as "women's solidarity" are portrayed as Western based, thus remaining marginal to the social norms in Turkey. The last linesuggests that male violence is an individual issue of "anger management," stripping the issue from its structural roots embedded in relations of patriarchal power and domination.

\section{Protecting the "cultural essence": Protecting the family}

KADEM's vision statement, declares that the organization is devoted to "conserving the essential values of women in Turkey,"13 implying that there are some predetermined, natural, and "essential" values that are or should be upheld by the society as a whole. In an interview with the national daily
Sabah newspaper, ${ }^{14}$ Sare Aydın Yllmaz argues that the feminist literature belongs strictly to the West and cannot be embraced by non-Western societies, contending that "every culture has a unique perspective when it comes to the woman issue." She further referencespostmodernism, as a global intellectual challenge to the domination of Western feminism to provide intellectual support to the position of upholding the "essential" and "authentic" cultural traits vs. "Western-based feminism" while promoting women's rights in Turkey.

In the same interview with Sabah, Yllmaz goes on to explain the rationale behind using the slogan "Overcome your anger if you are a man," arguing that this is exactly the slogan that will resonate with the particular cultural codes in Turkey:

Where does violence come from? Men. Who are the targets? Men. Then whom should the slogan address? It should address men. This slogan is ironic, yet it also encourages our own cultural codes... This is actually a challenge to men... Every culture has a perspective of its own. If you use this slogan in Sweden, maybe it will not have proper influence on society. You will make a better impression and have more of an impact when you conduct a campaign in accordance with the cultural essence. (Sabah, 1.12.2013)

Here, besides emphasizing that there is an essential core to the culture in Turkey, especially in terms of gender, she also supports naturalizing and preserving that "cultural essence" rather than even slightly questioning or challenging it. Moreover, it is taken for granted that addressing men and inviting them to abide by cultural codes that are allegedly "our own," rather than calling women to stand up against violence, is much more resonant with Turkey's "cultural essence".

The assumption of the "cultural essence" can also be traced throughout the columnists' support for KADEM and its campaign against male violence. For instance, Hilal Kaplan, a columnist for Yeni Şafak newspaper, which is also known for its close ties with the JDP government, celebrates the organization as follows:

KADEM is set to prove that the objectives of protecting cultural values and protecting women are not conflicting but rather complementary objectives. (Hilal Kaplan, Yeni Şafak, 27.11.2013)

What is meant by the particular "cultural values" is made clearer by Halime Kökçe, a columnist in Star newspaper:

Indeed, women are subjected to violence within their families. But can we prevent this violence by looking down on the family and praising alternative models of family? This obviously is not the right track. When we define male and female roles through a terminology that excludes family, the patriarchal structure reacts in the opposite way. Besides, the values of religion also necessitate a society to which family is central. Therefore, if we are to elevate women's status and give them equal rights with men, we have to avoid a language that is in conflict with the values of the society and religion, which strengthens those values. KADEM will handle the woman issue without excluding conservative values and without putting men in the position of "the other." (Halime Kökçe, Star, 28.11.2013) 
It is worth noting that Kökçe conflates "cultural" and "religious" values, without feeling the need to acknowledge which religion or which interpretation of Islam she is referring to. She is not only assuming that each and every citizen naturally subscribes to a religious belonging, she also assumes that source of religious belonging to be Islam. Even more problematic is the fact that she suggests appeasing "the patriarchal structure" so that it will not "react in the opposite way," a reaction which, in this case, presumably means inflicting more violence on women. It is suggested that the only way to appease this "patriarchal structure"-and protect women from even more angry husbands and fathers-is to avoid pointing out, criticizing, questioning the violence embedded in the family; an institution that should remain intact at all costs.

\section{Glorifying “honorable men," degrading "nagging” women}

The second line of argumentation that supports the KADEM campaign and the slogan "Overcome your anger if you are a man" manifests itself, first, through the glorification of values attributed to the "masculine" and second, through denouncing feminist discourse for being conflict based.

Hümeyra Şahin, a columnist for Akşam newspaper defends the slogan as follows:

This slogan (overcome your anger if you are a man) is not a conflict based call to a duel between men and women. Instead of a conflict based feminist discourse, the slogan is a call to men to come up to the task of being brave, being honourable, positive traits that are attributed to men by our culture. (Hümeyra Şahin, Akşam, 26.11.2013)

There are two different points raised by this quotation. First, the dichotomous gendered attributions are reinforced: the norms of hegemonic masculinity supported by "our culture" expect men to be naturally brave and honorable, and those who inflict violence on women are deviating from this "natural state" of being a man. Therefore, the solution to male violence lies in calling men to live up to the naturalized positive traits that are attributed to them. As there is no mention of the need for strict legal enforcement, the suggested solution to male violence boils down to asking men "nicely" to return to their "natural" state, praising them for their supposedly inherent attributes. Second, the columnist puts the blame on feminist discourse for calling duels between men and women.

Hümeyra Şahin is not alone in her attitude of accusing feminists for fanning the flame on male violence. When we delve further into the arguments presented in support of the campaign, it is clear that denouncing the language of women's solidarity and blaming feminists for upholding this language, is a common aspect. For instance, Elif Çakır, a columnist for the Star newspaper, contends that "Overcome your anger if you are a man" is a powerful slogan exactly because it speaks the language of the masculine by talking about power, as opposed to "nagging and whining" that she implicitly associates with the "feminine":

Women's associations in Turkey push women to an eternal secondary position, to the position of "the other" by using concepts like violence, protection, and solidarity. These words, or demands for quotas (in elections) only cause people to laugh up their sleeves.... This slogan calls on men to be proper men through a language of power, potency and authority, emphasizing manliness. Therefore it is as masculine a slogan as it is provocative. It uses a humorous, witty, masculine language, a language that men cannot laugh up their sleeves, a language which women can use with a smiling face while looking at men in the eye. I think it is marvellous. It is not whiney, there is no frowning victim discourse, there is no empty nagging. (Elif Çakır, Star, 1.12.2013)

The binary gendered oppositions reinforced in Çakır's column are noteworthy. According to her, to speak a language of power, potency, and authority means to speak the language of the masculine. Emphasizing power, potency, and authority means emphasizing virility, for these concepts are taken to belong to the realm of the masculine. Unless one speaks the language of the masculine, one is nagging and whining. Çakır's argumentation is puzzling, to say the least, as she first blames all women's associations (other than KADEM) for pushing women to a secondary position before condemning every utterance, every struggle that remains outside the "masculine language" for not being masculine enough. According to the columnist, uttering the possibility of women's solidarity leads to confining women to the position of "the other," the marginal, which is a position for nagging and whining women. The columnist suggests that this language is not to be taken seriously as it is to be mocked by men. Ironically, speaking the language of the masculine, and steering clear of concepts that suggest an active struggle and solidarity by women themselves figure as the fundamental standards by which to judge the success of a campaign against male violence. Accordingly, women who survive male violence are the very group of people who are to be excluded from the struggle against male violence. They are to be precluded from publicly "shouting out," for that kind of attitude would mean "empty nagging," placing them in the realm of the feminine as opposed to the masculine, thus marginalizing them in the eyes of men.

\section{Violence as an individual problem of "anger management"}

The third line of argumentation that supports the KADEM campaign formulates the problem of violence against women as an individual problem of "anger management," isolating the issue from the context of patriarchal relations of power and domination.

KADEM, by using the slogan "Overcome your anger if you are a man" hits the violence problem in the eye because it all starts in the inner world. Failure to control anger leads to violence. A small burst of violence spreads to society.... We know that anger is an emotional reaction to unwanted situations. Humans are humans because they are capable of controlling emotions. (Hümeyra Şahin, Akşam, 26.11.2013)

In this quotation, when the columnist argues that the problem starts at the individual level and then spreads to the society, she locates the problem at the individual level, overlooking its relation with gendered social norms and relations of power that breed violence. This line of argumentation complies conveniently with a conservative agenda on 
gender relations because it legitimizes the aversion from questioning the traditional family structure. The rhetoric of individualization of violence also legitimizes the difficult position of rendering women devoid of agency in the fight against violence: When solutions are sought in the personal ability to manage one's anger, it appears almost natural to hand all agency to men. As Seymour puts aptly, when violence against women is reduced to a problem of anger management, "women's safety is extricably linked to men, and, in particular, to men's willingness to control, protect and defend" (2011: 5).

Putting the emphasis on the individual and his ability to manage himself also hints at the neoliberal discourse of "management of the self" which shifts responsibility of problems "from society to the individual, thus leaving social structural problems largely intact" (Chen, 2010: 258). It has been argued that neo-liberal and neo-conservative agendas have been feeding one another in the last decade in Turkey, especially with regard to the "politics of intimate" (Acar \& Altunok, 2013). When it comes to the issue of violence against women, the rhetoric of "violence as an individual problem" lies at the intersection of neoliberal and conservative rationalities, for it both shifts responsibility to the individual and legitimizes the attitude of avoiding, if not totally abandoning, a discussion on substantial gender equality.

\section{Discussion}

One might indeed question whether it is wrong to address men and take them as interlocutors in the effort to prevent male violence. Not necessarily ${ }^{15}$. But the ways in which men are to be addressed makes all the difference. The problem with the campaign slogans "Overcome your anger if you are a man" and "Be a man first" is not that they address men. The problem is that the slogans and the campaign are invested in reinforcing and ossifying dominant norms of hegemonic masculinity as well as male domination, as if these play no part in the constant reproduction of violence against women. We argue that it is not possible to fight against male violence without opening a critical discussion about the connotations of "being a man" in Turkey, and the ways in which these connotations legitimize men's privilege to establish control over women.

In an article dealing with the question of whether engaging in violence against women is in any way relatable to dominant codes of hegemonic masculinity, Connell states the following:

I agree that in the public realm men who batter wives / partners are not cultural heroes. However ... In the informal culture of neighbourhoods, workplaces and pubs, husbands have been expected to keep wives in their place, and a man who can't do this has been regarded by other men with a degree of contempt. A controlled use of force, or the threat of force, has been widely accepted as part of men's repertoire in dealing with women and children as well as with other men.... Research with batterers and rapists indeed detects remorse and shame, (as Jefferson states) but also detects feelings of entitlement, justifications and the intention to establish control (2002: 93-94).

Obviously, when the supporters of the KADEM campaign suggest that the cure to male violence lies in calling men to "be men," they are assuming that the problem of violence against women, which is so vehemently widespread in Turkey, has no relation to the attribution of power, potency, and authority to men. Moreover, the three lines of argumentation in support of the campaign are bound by the assumption that one should avoid questioning and challenging the relations of power and domination which grant men the privilege and the "duty" to establish control over their partners, wives, children, as well as their own anger. Accordingly, a feminist questioning of male dominance results in men "laughing up their sleeves" at best, and provokes men to be more violent at worst. Hence, the need to appease men and resort to men's supposedly "inborn" ability to control and manage their anger while preventing women from engaging in an active political struggle against male violence. The obvious paradoxes and weaknesses in these assumptions and arguments are covered up by ambiguous and unsubstantiated references to a "cultural essence" in Turkey which supposedly requires avoiding a critical discussion on the patriarchal relations of power pervading social, political, and intimate realms.

\section{Conclusion}

The slogan "Overcome your anger if you are a man" was revealed as a part of KADEM's campaign against violence against women in 2013, aiming to raise awareness about increasing male violence damaging women's physical, sexual, and social integrity. This paper critically analyzes KADEM's campaign and its slogan through a perspective that emphasizes the relation between gendered power hierarchy and male violence. We employ the concept of hegemonic masculinity as it enables us to trace the relational multiple constructions of masculinities and femininities by remaining sensitive to the historical context. We discuss the discursive ground of the KADEM campaign with regard to the boundaries of an "institutionalized" system of the normative gender order in Turkey. However, while doing so, we look into the post-1980 women's movement and the possibilities it suggests in terms of subverting that normative gender order. An analysis of the discourse surrounding the KADEM campaign demonstrates how those possibilities are labeled as "marginal," and the tensions revolving around the very political act of critically engaging with what it means to be a man in Turkey.

Based on an analysis of the discursive ground of the campaign within which the slogan rests, three significant lines of argumentation were delineated. First, the campaign is publicized and promoted as an effort in accordance with the "cultural essence" in Turkey. In the framework of a delicate issue such as violence that transcends cultures and repeats itself, this argument hints at the idea of naturalizing traditional gender hierarchy within the society. The second line of argumentation is perilous as the campaign not only glorifies hegemonic masculine norms but also ostracizes a feminist agenda on violence as being Western or not a la Turca, i.e., Turkish. The final line of argumentation that this paper juxtaposes is about the problematic stripping of the issue of violence from its sexist and misogynist roots by taking it as a problem of anger management at individual level.

The urge to analyze the campaign is twofold for us. First, in Turkish political arena where masculinist norms have been reproduced not only at institutional but also discursive level, addressing man as the sole interlocutor masks the risk of disregarding woman's political agency. Additionally, in a parallel way, an analytical lens compatible with the post-1980 
feminist movement requires to voice women's own voices while the discursive ground surrounding the campaign stands in contrast. We argue that a fight against violence should first challenge gender inequalities based on hierarchical power relations undergirding violence or any other form of control and/or domination.

\section{Acknowledgments}

An earlier version of this paper was presented at the $1 \mathrm{st}$ International Symposium on Men and Masculinities, Izmir, Turkey (September 11-13, 2014). We would also like to thank Pelin Ayan Musil and Tobe Levin von Gleichen for their valuable comments.

\section{Endnotes}

${ }^{1}$ See KADEM (Women and Democracy Association) http://kadem.org.tr/ vizyonumuz/ last accessed on March 8, 2015.

2 See World Health Organization Media Centre http://www.who.int/ mediacentre/factsheets/fs239/en/ last accessed on April, 20, 2016.

${ }^{3}$ See Bianet http://www.bianet.org/english/women/161679-maleviolence-2014-infographic last accessed on February 20, 2015.

${ }^{4}$ The title of the Law 6248 is "The Law to Protect Family and Prevent Violence Against Women". This title has been criticized for locating "the family" over the individual, and for reflecting the assumption that women are necessarily a part of family rather than individuals. (Sener, 2012).

${ }^{5}$ See KADEM (Kadın ve Demokrasi Derneği) http://kadem.org.tr/thewomen-and-democracy-association-kadem/ last accessed on March 6, 2015

${ }^{6}$ See KADEM (Kadın ve Demokrasi Derneği) http://kadem.org.tr/thewomen-and-democracy-association-kadem/ last accessed on March 6, 2015.

${ }^{7}$ For a detailed analysis of masculinity studies, feminism and their relations with reference to their engagement with male violence see McCarry, 2007.

8 'Finding one's own voice' is a telling metaphor for finding ways to express subjugated experiences. In a documentary about the post-1980 feminist movement, Gülnur Savran, a feminist academic and a movement activist talks about the difficulties she had in terms of 'speaking out' in the male dominated socialist gatherings in the 1970's. She explains that her 'voice' (literally) came out like a teenager boy's voice, shaky and insecure, also denoting her insecurity in terms of speaking her mind under the disapproving male gazes. (Özman, Melek (Director) (2008) İsyan-I Nisvan (Women's Rebellion) [Documentary] Turkey: Filmmor Women's Cooperative. )

${ }^{9}$ See Mor (Purple) http://mor.blogcu.com/bagir-herkes-duysun/184782-. last accessed on March 5, 2015.

${ }^{10}$ For a detailed account of the history of violence against women in Turkey, and especially for the contribution of KAMER (Kadın Merkezi Women's Center) established in 1997, see Altınay \& Arat, 2008.

${ }^{11}$ President Erdoğan's daughter, SümeyyeErdoğan is among the members of the Board of Directors of KADEM.

12 "Kadın ile erkeği eşit konuma getiremezsiniz çünkü o fitrata terstir" (You cannot make men and women equal because it is against the fitrat), Milliyet, 24.11.2014, http://www.milliyet.com.tr/erdogan-batsin-bu-dunya/siyaset/ detay/1974189/default.htm. last accessed on December 29, 2014.

13 http://kadem.org.tr/vizyonumuz/ last accessed on December 29, 2014.

14 “Erkeksen öfkeni yen diyerekironiyaptık", Sabah, 1.12.2013.http://www. sabah.com.tr/pazar/2013/12/01/erkeksen-ofkeni-yen-diyerek-ironi-yaptik last accessed on December 29, 2014.

${ }^{15}$ For instance, there are recent efforts in Turkey initiated by men to fight against male violence, such as Rahatsız Erkekler (Uncomfortable Men) and Ataerkiye Karşı Erkekler (Men against Patriarchy). These activist groups are significant not only because they mobilize men to fight against male violence but also because they encourage the questioning of masculinist norms, sexism and gender violence by men themselves.

\section{References}

Acar, Feride, \& Altunok, Gülbanu (2013). The 'politics of intimate' at the intersection of neo-liberalism and neo-conservatism. Women's Studies International Forum, 41(1), 14-23.
Akal, Emel Aslan (1996). Women and socialism in Turkey: Case of progressive women's organization. MSc Thesis METU.

Altınay, Ayșe Gül, \& Arat, Yeșim (2008). Türkiye'de Kadına Yönelik Siddet [Violence against women in Turkey]. İstanbul: Metis Yayınları.

Arat, Yeşim (1989). Patriarchal paradox, women politicans in Turkey. Cranbury, NJ: Associated University Presses.

Arat, Yeşim (1997). The project of modernity and women in Turkey. In S. Bozdoğan, \& R. Kasaba (Eds.), Rethinking Modernity and National Identity in Turkey (pp. 95-111). Seattle: University of Washington Press.

Arat, Yeşim (1999). Democracy and women in Turkey: In defense of liberalism. Social Politics, 6(3), 370-387.

Aydin Yılmaz, Sare (2014). Eşitlik Üstü Adalet (Justice Above Equality). Star Daily Newspaper, 13.12 http://haber.stargazete.com/acikgorus/esitlik-ustuadalet/haber-980329. (Last Access: 29.12.2014).

Berktay, Fatmagül (2001). Osmanlı'dan Cumhuriyet'e Feminizm [Feminism from the Ottoman Empire to the Republic]. In T. Bora, \& M. Gültekin (Eds.), Tanzimat ve Meșrutiyet'in Birikimi [The Accumulation of Tanzimat and Constitutional Period] (pp. 348-361). İstanbul: İletişim.

Bora, Tanıl, \& Tol, Ulaș (2009). Siyasal Düșünce ve Erkek Dili [Political Thought and Masculine Language]. Modern Türkiye'de Siyasi Düşünce. Cilt 9 Dönemler ve Zihniyetler [Periods and Mindsets] (pp. 825-836). İstanbul: İletişim Yayınları.

Bourdieu, Pierre (2001). Masculine domination. Cambridge: Polity Press.

Brittan, Arthur (1989). Masculinity and power. Oxford: Basil Blackwell.

Bryson, Valerie (1992). Feminist political theory: An introduction. Hampshire and London: MacMillan.

Çakır, Elif (2013). Haydi erkeksen! (Come on if You Are a Man!). Star Newspaper, 1 December. http://haber.star.com.tr/yazar/haydi-erkeksen/ yazi-811570 (Last access: 28.04.2015)

Chen, Eva (2010). Neoliberal self-governance and popular post-feminism in contemporary Anglo-American chick-lit. Concentric: Literary and Cultural Studies, 36(1), 243-275.

Connell, Raewyn (1987). Gender and power: Society, the person and sexual politics. Cambridge: Polity Press.

Connell, Raewyn (1990). An iron man: The body and some contradictions on hegemonic masculinities. In Michael Messner, \& Donald Sabo (Eds.), Sport, men and gender order: Critical feminist perspective (pp. 83-95). Champaign: Human Kinetics.

Connell, Raewyn (2002). On hegemonic masculinity and violence. Theoretical Criminology, 6(1), 89-99.

Connell, Raewyn (2005). Masculinities. Los Angeles: University of California Press.

Connell, Raewyn, \& Messerschmidt, James W. (2005). Hegemonic masculinity: Rethinking the concept. Gender \& Society, 19(6), 829-859.

Coşar, Simten, \& Yeğenoğlu, Metin (2011). New grounds for patriarchy in Turkey? Gender policy in the age of AKP. South European Society and Politics, 16(4), 555-573.

Flood, Michael (2011). Involving men in efforts to end violence against women. Men and Masculinities, 14(3), 358-377.

Greig, Alan (2001). Political connections: Men, gender and violence'. Working paper series on men's roles and responsibilities in ending gender based violence: Working paper no. 1. INSTRAW (accessed online at http://www. health.columbia.edu/pdfs/men_gender_violence.pdf).

Güvenç, Gülten, Akyüz, Aygül, \& Sandra, Cesario (2014). Intimate partner violence against women in Turkey: A synthesis of the literature. Journal of Family Violence, 29, 333-341.

Hawkesworth, Mary (2005). Engendering political science: An immodest proposal. Politics and Gender, 1(1), 141-156.

Hartsock, Nancy (1983). Money, sex and power: Toward a feminist historical materialism. New York: Longman.

Hooper, Charlotte (2001). Manly states: Masculinites, international relations and gender politics. New York: Columbia University Press.

Kandiyoti, Deniz (1987). Emancipated but unliberated? Reflections on the Turkish case. Feminist Studies, 13(2), 317-338.

Kann, Mark (1998). Republic of men: The American founders, gendered language, and patriarchal politics. New York: New York University Press.

Kaplan, Hilal (2013). Erkeksen... (if you are a man...). Yeni Șafak Newspaper, 27 November. http://www.yenisafak.com.tr/yazarlar/HilalKaplan/erkeksen/ 42312 (Last access: 28.04.2015)

Kegan Gardiner, Judith (2005). Men, masculinities, and feminist theory. In Michael Kimmel, Jeff Hearn, \& Raewyn Connell (Eds.), Handbook of studies on men and masculinities (pp. 35-50). London: Sage Publications Ltd.

Kimmel, Michael, Hearn, Jeff, \& Connell, Raewyn (Eds.). (2005). Handbook of studies on men and masculinities. London: Sage Publications Ltd.

Kökçe, Halime (2013). Erkek-sen Destur (Make way if you are a man). Star Newspaper, 28 November. http://haber.stargazete.com/yazar/erkeksendestur/yazi-810595 (Last access: 28.04.2015)

McCarry, Melanie (2007). Masculinity studies and male violence: Critique or collusion? Women's Studies International Forum, 30, 404-415. 
McCormack, Matthew (Ed.). (2007). Public men: political masculinities in modern Britain. Basingstoke: Palgrave Macmillan.

Onar, Nora, \& Müftüler-Baç, Meltem (2011). The adultery and the headscarf debates in Turkey: fusing "EU-niversal" and "alternative" modernities? Women's Studies International Forum, 34(5), 378-389.

Özçürümez, Saime, \& Sayan-Cengiz, Feyda (2011). On resilience and response beyond value change: Transformation of women's movement in post-1980 Turkey. Women's Studies International Forum, 34(1), 20-30.

Özman, Melek (Director) (2008). İsyan-1 Nisvan [Women's Rebellion] (Documentary) Turkey: Filmmor Women's Cooperative.

Parpart, Jane, \& Zalewski, Marysia (2008). Rethinking the man question: Sex gender and violence in international relations. London: Zed Books.

Pateman, Carol (1988). The sexual contract. California: Stanford University Press.

Pitkin, Hanna (1984). Fortune is a woman: Gender and politics in the thought of Niccolo Machiavelli. Berkeley: University of California Press.

Şahin, Hümeyra (2013). Erkeksen öfkeni yen (Overcome your anger if you are a man). Akșam Newspaper, 26 November. http://www.aksam.com.tr/ yazarlar/erkeksen-ofkeni-yen-c2/haber-264012 (Last access: 28.04.2015)

Sener, Ülker (2012). “6284 Sayılı Ailenin Korunması ve Kadına Yönelik Şiddetin Önlenmesine Dair Kanun Ne Getiriyor?” TEPAV Değerlendirme Notu, No: 201220. http://www.tepav.org.tr/upload/files/1333026809-1. 6284_Sayili_Ailenin_Korunmasi_ve_Kadina_Yonelik_Siddetin_Onlenmesine_ Dair_Kanun_Ne_Getiriyor.pdf (Last access: 3.2.2015)
Seymour, Kate (2011). (Re)Gendering Violence: Men, Masculinities and Violence. ANZCCC: The Australian and New Zealand Critical Criminology Conference 2010. Institute of Criminology, Sydney Law School, The University of Sydney.

Sirman, Nükhet (1989). Feminism in Turkey: A short history. New Perspectives on Turkey, 3(1), 1-34.

Starck, Katleen, \& Sauer, Birgit (Eds.). (2014). A man's world? Political masculinities in literature and culture. Cambridge: Scholars Publishing.

Tekeli, Sirin (1986). Emergence of the feminist movement in Turkey. In Drude Dahlerup (Ed.), The New Women's Movement (pp. 179-199). London: Sage.

Tekeli, Sirin (1990). Women in changing political associations of the 1980s. In Andrew Finkel, \& Nükhet Sirman (Eds.), Turkish state, Turkish society (pp. 259-288). London: Routledge.

Ünal, Didem, \& Cindoğlu, Dilek (2013). Reproductive citizenship in Turkey: Abortion chronicles. Women's Studies International Forum, 38, 21-31.

Yanagisako, Sylvia, \& Delaney, Carol (Eds.). (1994). Naturalizing power: Essays in feminist cultural analysis. New York: Routledge.

Zihnioğlu, Yaprak (2003). Kadınsız İnkılap (revolution without women). İstanbul: Metis. 